\title{
National Assessment of Helium Resources Within Known Natural Gas Reservoirs
}

Scientific Investigations Report 2021-5085 



\section{National Assessment of Helium Resources Within Known Natural Gas Reservoirs}

By Sean T. Brennan, Jennifer L. Rivera, Brian A. Varela, and Andy J. Park

Scientific Investigations Report 2021-5085 


\section{U.S. Geological Survey, Reston, Virginia: 2021}

For more information on the USGS - the Federal source for science about the Earth, its natural and living resources, natural hazards, and the environment—visit https://www.usgs.gov or call 1-888-ASK-USGS.

For an overview of USGS information products, including maps, imagery, and publications, visit https://store.usgs.gov/.

Some of the data used for this assessment either are not available or have limited availability because the private entities that compiled the data have a proprietary interest in them. For more information on the sources of these data, please contact the U.S. Geological Survey Eastern Energy Resources Science Center in Reston, Va.

Any use of trade, firm, or product names is for descriptive purposes only and does not imply endorsement by the U.S. Government.

Although this information product, for the most part, is in the public domain, it also may contain copyrighted materials as noted in the text. Permission to reproduce copyrighted items must be secured from the copyright owner.

Suggested citation:

Brennan, S.T., Rivera, J.L., Varela, B.A., and Park, A.J., 2021, National assessment of helium resources within known natural gas reservoirs: U.S. Geological Survey Scientific Investigations Report 2021-5085, 5 p., https://doi.org/10.3133/sir20215085.

Associated data release:

Brennan, S.T., East, J.A., Dennen, K.O., Jahediesfanjani, H., and Varela, B., 2021, Dataset of helium concentrations in United States wells: U.S. Geological Survey data release, accessed June 14, 2021, at https://doi.org/10.5066/P920L79J.

ISSN 2328-0328 (online 


\section{Acknowledgments}

This work could not have been done without assistance from the Bureau of Land Management's Federal Helium Program and access to their internal datasets and reports. Thanks to John Hamak, Dave Driskill, and Joe Peterson from the Bureau of Land Management for help understanding and updating their gas compositional dataset and internal datasets and reports; their assistance was critical in this effort. U.S. Geological Survey colleagues helped with the initial dataset work, including Joseph East, Kristin Dennen, Ryan Creitz, and Hossein Jahediesfanjani. Thanks to helpful reviews from Matthew Merrill, Rama Kotra, and Jenna Shelton, which improved the report immensely. 



\section{Contents}

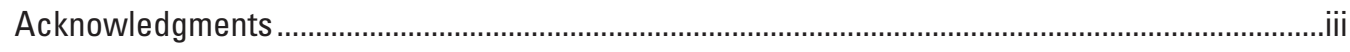

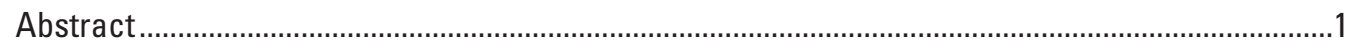

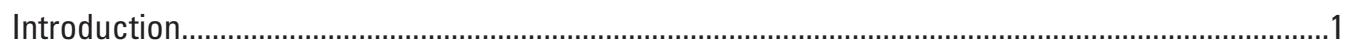

Sources

Methods

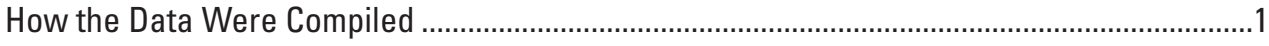

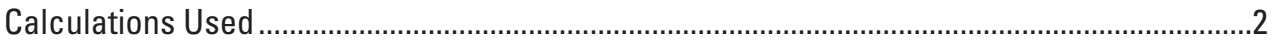

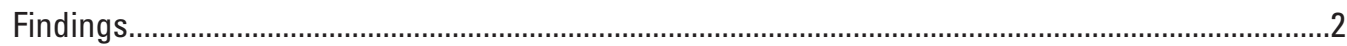

References Cited.

\section{Figure}

1. Map of the continental United States indicating the seven Bureau of Land Management-proposed regions for which the recoverable helium resource estimates in this report are given

\section{Table}

1. Estimates by the U.S. Geological Survey in 2020 of national totals for recoverable helium resources from known natural gas reservoirs, by Bureau of Land Management-proposed helium-resource region 


\section{Conversion Factors}

U.S. customary units to International System of Units

\begin{tabular}{|c|c|c|}
\hline Multiply & By & To obtain \\
\hline cubic foot $\left(\mathrm{ft}^{3}\right)$ & 28.32 & cubic decimeter $\left(\mathrm{dm}^{3}\right)$ \\
\hline cubic foot $\left(\mathrm{ft}^{3}\right)$ & 0.02832 & cubic meter $\left(\mathrm{m}^{3}\right)$ \\
\hline
\end{tabular}

\section{Abbreviations}

$\begin{array}{ll}\text { BCF } & \text { billion cubic feet } \\ \text { BLM } & \text { Bureau of Land Management } \\ \text { CRD } & \text { Comprehensive Resource Database } \\ \text { EGDB } & \text { Energy Geochemistry Database } \\ \text { USBM } & \text { U.S. Bureau of Mines } \\ \text { USGS } & \text { U.S. Geological Survey }\end{array}$




\title{
National Assessment of Helium Resources Within Known Natural Gas Reservoirs
}

\author{
By Sean T. Brennan, Jennifer L. Rivera, Brian A. Varela, and Andy J. Park
}

\section{Abstract}

Using available data, the U.S. Geological Survey estimated that 306 billion cubic feet of recoverable helium is presently within the known geologic natural gas reservoirs of the United States.

\section{Introduction}

The Helium Stewardship Act of 2013 (Public Law 113-40) directed the U.S. Geological Survey (USGS) to create an accounting of the geologic helium resources of the United States (U.S. Congress, 2013). Helium is a nonrenewable resource that is produced from the subsurface, typically in conjunction with other gases. These coproduced gases are either hydrocarbon rich, inert, or a mixture of the two. Unlike other USGS natural resource assessments, which have focused on undiscovered resources, this assessment is an estimate of the volume of producible helium currently remaining in known gas accumulations within the United States.

\section{Sources}

Most of the helium concentration data used for this assessment are from data generated by the Federal Helium Program - a program that was established in 1925 under the U.S. Bureau of Mines (USBM) and which, since 1995, has been administered by the U.S. Department of the Interior's Bureau of Land Management (BLM). As part of their work under the Federal Helium Program, researchers collected and analyzed data on the geochemical composition of gases produced from hydrocarbon wells to identify potential sources of helium. Their analyses were reported in several publications, including Moore and Sigler (1987), Hamak and Sigler (1991, 1993), Hamak and Gage (1992), Sigler (1994), Hamak and Driskill (1996), Gage and Driskill (1998, 2003, 2005), and Driskill (2008). Additional unpublished data from the program that reside in an internal BLM database were made available to the USGS for this assessment. These Federal Helium Program data were supplemented with additional gas compositional analysis data from the USGS Energy Resources Program's Energy Geochemistry Database (EGDB) (U.S. Geological Survey, 2019a). The helium concentration data sourced from the Federal Helium Program, and the EGDB are available in tabular format in Brennan and others (2021) and as an interactive map in U.S. Geological Survey (2019b). Additional well location data and reservoir property data were obtained from other sources, including the USGS Comprehensive Resource Database (CRD) (Carolus and others, 2017), the IHS well database (IHS Markit Ltd., 2019; formerly IHS Inc.), and internal BLM reports and datasets. The USGS CRD was created from the Nehring Resource Group's database of hydrocarbon reservoirs (Nehring Associates, Inc., 2012), from the field-level production and well-count data in the well database developed by IHS Markit Ltd. (2019), and from several other sources (Carolus and others, 2017, p. 3).

\section{Methods}

\section{How the Data Were Compiled}

The commonly accepted cutoff for commercial viability of helium recovery and processing is a gas containing 0.3 mole percent helium (National Research Council, 2010). Gas reservoirs with 0.3 mole percent helium are typically referred to as "helium-rich" reservoirs, whereas those with lower concentrations are referred to as being "helium-lean" reservoirs (Pacheco, 2008). To prepare this assessment, data on the individual gas reservoirs shown to have at least one helium concentration value of 0.3 mole percent or greater (sufficient to be considered helium rich) were culled from the Federal Helium Program and the USGS EGDB gas compositional value datasets. Isolating the data for the helium-rich reservoirs enabled the assessment to focus on the most likely candidates for helium production. There were 1,217 reservoirs that met the criteria of having at least one helium concentration value equal to or greater than 0.3 mole percent, and for these reservoirs, a total of 4,543 helium concentration analyses had been conducted.

The culled list of 1,217 reservoirs and their respective helium concentration data were merged with reservoir data to compile a composite dataset that includes all the required 
data parameters for the assessment. These parameters are (1) the original volume of gas in place, (2) the recovery factor that indicates how much of the original gas in place could be produced, (3) the total volume of gas produced to date, and (4) the concentration of helium in the produced gas. The bulk of the reservoir data for this compilation step are from the USGS CRD (Carolus and others, 2017) and the BLM internal databases. Linking the helium concentration from individual wells to the reservoirs in the CRD and the BLM internal reports and databases was accomplished using data from the IHS well database (IHS Markit Ltd., 2019). The IHS well database also was used to obtain gas production values for reservoirs not included in the CRD or in BLM reports and databases as well as more recent production data for the reservoirs that are included in the CRD and BLM sources. Of the 1,217 reservoirs from the composite dataset, 481 reservoirs and a total of 3,127 compositional analyses had matching information for the original volume of gas in place, the recovery factor, and the total volume of gas produced to date. These 481 reservoirs represent approximately $2 \%$ of all gas reservoirs from significant petroleum fields in the United States. This study uses "significant petroleum fields" to mean fields with a known recovery (the sum of cumulative production and proved reserves) of 500,000 barrels of oil equivalent ( 3 billion cubic feet of gas) or more (Nehring Associates, Inc., 2012).

\section{Calculations Used}

To assess the volume of remaining helium in the identified reservoirs, it was necessary to estimate the volume of recoverable gas and the concentration of helium in that gas. To determine the volume of the recoverable gas, the following equation was used:

$$
\begin{gathered}
\text { (Original Gas in Place } \times \text { Recovery Factor) } \\
\quad-\text { Produced Gas } \\
=\text { Volume of Recoverable Gas }
\end{gathered}
$$

If the original gas-in-place values and recovery factors for a given reservoir were not reported in any of the available databases but the annual gas production values were reported, then the volume of recoverable gas was estimated using decline curve analysis of the annual production volumes (Fetkovich and others, 1996).

To determine the volume of recoverable helium remaining in each reservoir, the following equation was used:

$$
\begin{gathered}
\text { Volume of Recoverable Gas } \\
\times \text { Helium Concentration } \\
=\text { Volume of Remaining Recoverable Helium }
\end{gathered}
$$

For the statistical analysis used to create this assessment, a Monte Carlo simulation was selected because it allows one to enter ranges instead of fixed values for each component of the equations (Blondes and others, 2013). Using ranges of values for the inputs and outputs of the equations instead of fixed values helps account for the uncertainties inherent in geologic data. Because the input values are ranges, Monte Carlo simulations produce outputs that are distributions rather than fixed values, and the resulting assessment is therefore fully probabilistic. This assessment used ranges of helium concentration data and recoverable gas data from the 481 reservoirs for which all the data required to populate the Monte Carlo simulation were available.

\section{Findings}

The mean volume of recoverable helium in the United States is estimated to be 306 billion cubic feet (BCF), as shown in table 1. In terms of the helium-resource regions proposed by the BLM (fig. 1), most of the recoverable helium is from the Mid-Continent region, which has an estimated $156 \mathrm{BCF}$ of recoverable helium, by volume, and the Rocky Mountain region, which has an estimated $148 \mathrm{BCF}$; the other regions together account for less than $2.5 \mathrm{BCF}$. There is also less than 3 BCF of helium present in the Federal helium reserve at Cliffside field near Amarillo, Texas (Peterson, 2021); however, this volume of helium is not included in the assessment results.

Table 1. Estimates by the U.S. Geological Survey in 2020 of national totals for recoverable helium resources from known natural gas reservoirs, by Bureau of Land Management-proposed helium-resource region.

$\left[\mathrm{P}_{5}, \mathrm{P}_{50}\right.$, and $\mathrm{P}_{95}$ are probability percentiles and represent the 5-, 50-, and 95-percent probabilities, respectively, that the true resource is less than the value shown. The terminology used differs from that used by the petroleum industry and follows standard statistical practice (for example, Everitt and Skrondal, 2010), where percentiles, or fractiles, represent the value of a variable below which a certain proportion of observations falls. Resources in Hawaii and federally owned offshore areas were not assessed. BCF, billion cubic feet; - , no resources identified]

\begin{tabular}{lcccc}
\hline \multirow{1}{*}{ Region } & \multicolumn{5}{c}{ Helium in identified reservoirs (BCF) } \\
\cline { 2 - 5 } & $\mathbf{P}_{\mathbf{5}}$ & $\mathbf{P}_{\mathbf{5 0}}$ & $\mathbf{P}_{\mathbf{9 5}}$ & $\begin{array}{c}\text { Estimated } \\
\text { mean }\end{array}$ \\
\hline Alaska & 0.01 & 0.04 & 0.09 & 0.04 \\
Atlantic & - & - & - & - \\
Gulf Coast & 0.21 & 0.43 & 0.75 & 0.45 \\
Mid-Continent & 96 & 152 & 228 & 156 \\
North Central & 1.2 & 1.9 & 2.8 & 1.9 \\
Pacific & - & - & - & - \\
Rocky Mountain & 122 & 147 & 176 & 148 \\
Total United States & 231 & 302 & 394 & 306 \\
\hline
\end{tabular}




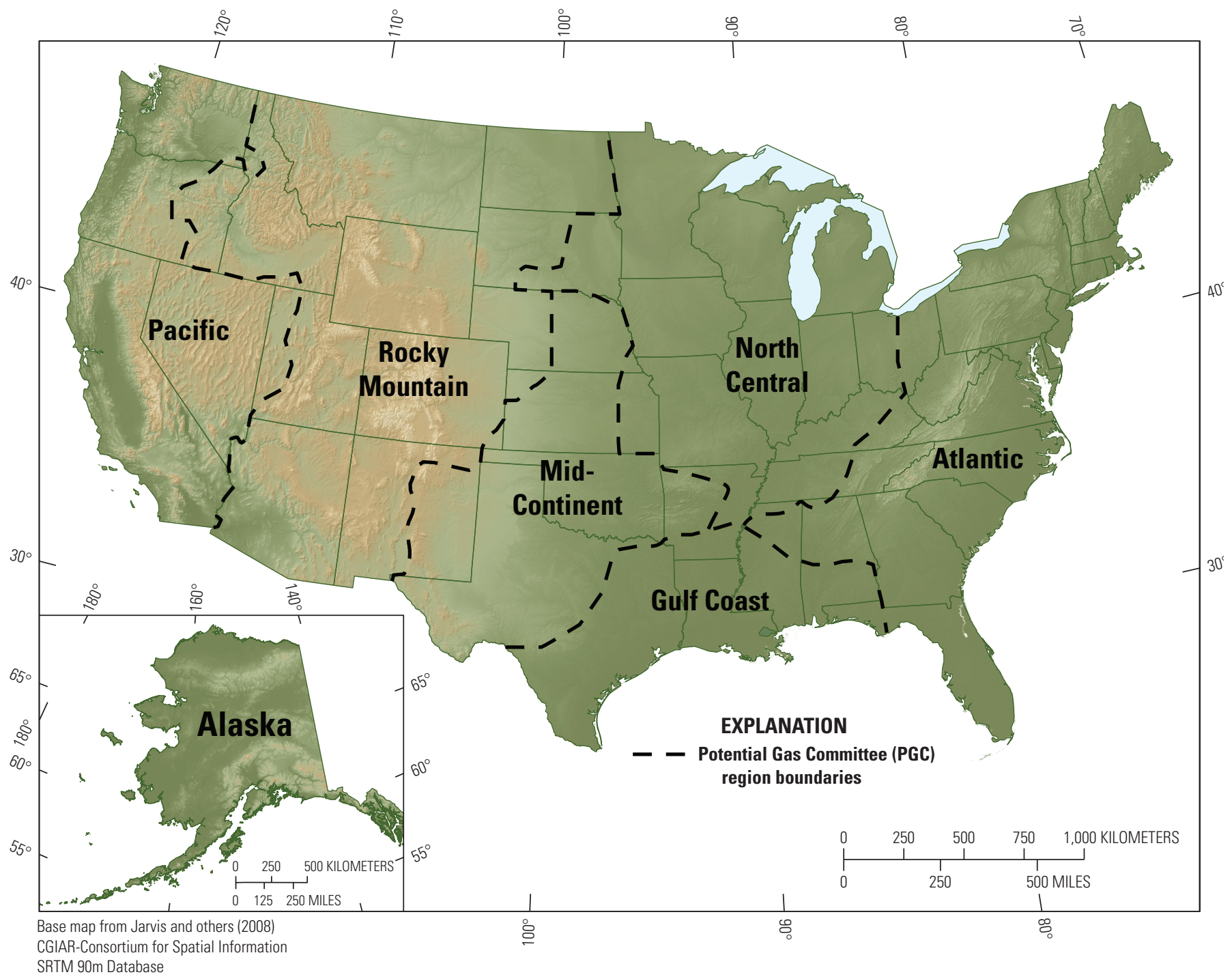

Figure 1. Map of the continental United States indicating the seven regions proposed by the Bureau of Land Management (BLM) (Pacheco and Ali, 2008, fig. 1). Helium resources assessed in this report are apportioned into these BLM-defined regions. Resources in Hawaii and federally owned offshore areas were not assessed. The regions are plotted over a shaded-relief image showing higher elevations in brown and tan and lower elevations in green. 


\section{References Cited}

Blondes, M.S., Brennan, S.T., Merrill, M.D., Buursink, M.L., Warwick, P.D., Cahan, S.M., Corum, M.D., Cook, T.A., Craddock, W.H., DeVera, C.A., Drake, R.M., II, Drew, L.J., Freeman, P.A., Lohr, C.D., Olea, R.A., Roberts-Ashby, T.L., Slucher, E.R., and Varela, B.A., 2013, National assessment of geologic carbon dioxide storage resources-Methodology implementation: U.S. Geological Survey Open-File Report 2013-1055, 27 p., accessed August 23, 2021, at https://doi.org/10.3133/ofr20131055.

Brennan, S.T., East, J.A., Dennen, K.O., Jahediesfanjani, H., and Varela, B., 2021, Dataset of helium concentrations in United States wells: U.S. Geological Survey data release, accessed June 14, 2021, at https://doi.org/10.5066/P92QL79J.

Carolus, M., Biglarbigi, K., Warwick, P.D., Attanasi, E.D., Freeman, P.A., and Lohr, C.D., 2017, Overview of a comprehensive resource database for the assessment of recoverable hydrocarbons produced by carbon dioxide enhanced oil recovery (ver. 1.1, June 2018): U.S. Geological Survey Techniques and Methods, book 7, chap. C16, 31 p., accessed June 14, 2021, at https://doi.org/10.3133/tm7C16.

Driskill, D.L., 2008, Analyses of natural gases, 2005-2007: Bureau of Land Management Technical Note 427, 199 p., accessed June 14, 2021, at https://www.blm.gov/sites/blm.gov/files/documents/files/ Library_BLMTechnicalNote427.pdf.

Everitt, B.S., and Skrondal, A., 2010, The Cambridge dictionary of statistics (4th ed.): Cambridge, England, Cambridge University Press, $478 \mathrm{p}$.

Fetkovich, M.J., Fetkovich, E.J., and Fetkovich, M.D., 1996, Useful concepts for decline curve forecasting, reserve estimation, and analysis: SPE Reservoir Engineering, v. 11, no. 1, p. 13-22, accessed June 14, 2021, at https://doi.org/10.2118/28628-PA.

Gage, B.D., and Driskill, D.L., 1998, Analyses of natural gases, 1996-1997: Bureau of Land Management Technical Note 404, 71 p., accessed June 14, 2021, at https:// ia800604.us.archive.org/14/items/analysesofnatura00gage/ analysesofnatura00gage.pdf.

Gage, B.D., and Driskill, D.L., 2003, Analyses of natural gases, 1998-2001: Bureau of Land Management Technical Note 412, 173 p., accessed June 14, 2021, at https://www.blm.gov/sites/blm.gov/files/documents/files/ Library_BLMTechnicalNote412.pdf.

Gage, B.D., and Driskill, D.L., 2005, Analyses of natural gases, 2002-2004: Bureau of Land Management Technical Note 418, 243 p., accessed June 14, 2021, at https://www.blm.gov/sites/blm.gov/files/documents/files/ Library_BLMTechnicalNote418.pdf.
Hamak, J.E., and Driskill, D.L., 1996, Analyses of natural gases, 1994-95: Bureau of Land Management Technical Note 399, 68 p., accessed June 14, 2021, at https:// ia800606.us.archive.org/10/items/analysesofnatura00hama/ analysesofnatura00hama.pdf.

Hamak, J.E., and Gage, B.D., 1992, Analyses of natural gases, 1991: U.S. Bureau of Mines Information Circular 9318, 97 p., accessed June 14, 2021, at https://books.google.com/ books?id=r3Hv4X4rhs4C\&pg=PP3\&source=gbs_selected pages $\&$ cad $=2 \# \mathrm{v}=$ onepage $\& \mathrm{q} \& \mathrm{f}=$ false.

Hamak, J.E., and Sigler, S., 1991, Analyses of natural gases, 1986-90: U.S. Bureau of Mines Information Circular 9301, 315 p., accessed June 14, 2021, at https://ntrl.ntis.gov/NTRL/dashboard/searchResults/ titleDetail/PB92154863.xhtml.

Hamak, J.E., and Sigler, S.M., 1993, Analyses of natural gases, 1992: U.S. Bureau of Mines Information Circular 9356, 62 p., accessed June 14, 2021, at https://ntrl.ntis.gov/NTRL/ dashboard/searchResults/titleDetail/PB93227437.xhtml.

IHS Markit Ltd., 2019, PIDM [Petroleum Information Data Model] relational U.S. well data [data current as of May 9, 2019]: Englewood, Colo., IHS Markit Ltd. [formerly IHS Inc.] database.

Jarvis, A., Reuter, H.I., Nelson, A., and Guevara, E., 2008, Hole-filled SRTM [Shuttle Radar Topographic Mission] for the globe version 4, available from the CGIARCSI [Consultative Group for International Agricultural Research-Consortium for Spatial Information] SRTM 90m database: Consultative Group for International Agricultural Research - Consortium for Spatial Information database, accessed January 15, 2012, at https://cgiarcsi.community/ data/srtm-90m-digital-elevation-database-v4-1/.

Moore, B.J., and Sigler, S.M., 1987, Analyses of natural gases, 1917-1985: U.S. Bureau of Mines Information Circular 9129, 1,197 p., accessed June 14, 2021, at https://ntrl.ntis.gov/NTRL/dashboard/searchResults/ titleDetail/PB87232211.xhtml.

National Research Council, 2010, Selling the Nation's helium reserve: Washington, D.C., The National Academies Press, 156 p., accessed June 14, 2021, at https://doi.org/10.17226/12844.

Nehring Associates, Inc., 2012, The significant oil and gas fields of the United States database [data current as of December 2010].: Colorado Springs, Colo., Nehring Associates, Inc.

Pacheco, N., 2008, Helium: U.S. Geological Survey Mineral Commodity Summaries 2008, p. 78-79, accessed June 14, 2021, at https://s3-us-west-2.amazonaws.com/ prd-wret/assets/palladium/production/mineral-pubs/helium/ mcs-2008-heliu.pdf. 
Pacheco, N., and Ali, S.F., 2008, Helium resources of the United States - 2007: Denver, Colorado, Bureau of Land Management Technical Note 429, BLM/NM/ ST-09/001+3745, 20 p., accessed June 14, 2021, at https://www.blm.gov/sites/blm.gov/files/Helium \%20Resources\%20of\%20the\%20US\%202007_508.pdf.

Peterson, J.B., 2021, Helium, in U.S. Geological Survey, 2021, Mineral commodity summaries 2021: Reston, Va., U.S. Geological Survey, p. 76-77, accessed June 14, 2021, at https://pubs.usgs.gov/periodicals/mcs2021/mcs2021helium.pdf.

Sigler, S.M., 1994, Analyses of natural gases, 1993:

U.S. Bureau of Mines Information Circular 9400, 58 p., accessed June 14, 2021, at https://ntrl.ntis.gov/NTRL/ dashboard/searchResults/titleDetail/PB94204039.xhtml.
U.S. Congress, 2013, Helium Stewardship Act of 2013Public Law 113-40: Washington, D.C., U.S. Government Printing Office, 15 p., accessed June 14, 2021, at https://www.congress.gov/113/plaws/publ40/PLAW113publ40.pdf.

U.S. Geological Survey, 2019a, Energy Geochemistry Database (EGDB): U.S. Geological Survey provisional database, accessed June 14, 2021, at https://certmapper.cr.usgs.gov/data/apps/ geochem-db/.

U.S. Geological Survey, 2019b, National helium dataset web map: U.S. Geological Survey web map, accessed June 14, 2021, at https://eerscmap.usgs.gov/heapp/.
For more information about this report, contact:

Energy Resources Program

U.S. Geological Survey

12201 Sunrise Valley Drive

Reston, VA 20192

Telephone: 703-648-6470

https://www.usgs.gov/energy-and-minerals/energy-resourcesprogram/connect 


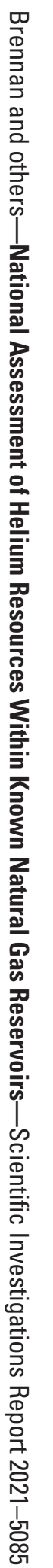

